\title{
Addition of silicate or organic fertilizer increases growth and yield of several varieties of maize in East Lombok, Indonesia
}

\author{
Andrayani Endang Tatik ${ }^{1}$, Wayan Wangiyana ${ }^{2 *}$ \\ ${ }^{1}$ SMK Tahfidz Arrobbani Wanasaba, East Lombok, Indonesia \\ ${ }^{2}$ Department of Agronomy, Faculty of Agriculture, University of Mataram, Mataram, Indonesia \\ *Corresponding Author E-mail: w.wangiyana@unram.ac.id
}

\begin{abstract}
Article Info:
First submitted:

May $11^{\text {th }}, 2021$

Revised:

June $10^{\text {th }}, 2021$

Accepted:

June $15^{\text {th }}, 2021$

Published online:

June $30^{\text {th }}, 2021$

Corresponding author:

W. Wangiyana

Keywords:

Organic;

Silicate;

Maize;

NPK;

fertilizer

Abstract. Many have reported that application of Silicon ( $\mathrm{Si}$ ) can alleviate environmental stress and increase grain yield of maize plants under stresses. This study aimed to examine the effects of adding organic or silicate fertilizer on several varieties of maize in rainfed area during a dry season, by conducting field experiment designed with Randomized Complete Block Design testing two treatment factors, i.e. maize varieties $(\mathrm{V} 1=$ Bisi-2, V2 $=$ Srikandi, V3 $=$ Pioneer -27$)$ and fertilizer combinations $(F 1=$ NPK only, F2= NPK+organic, F3= NPK+silicate). Results indicated that there were significant effects of fertilizer combinations and varieties on growth and yield of several maize varieties, in which the mean values were highest in maize plants fertilized with $\mathrm{NPK}+$ silicate fertilizers, except harvest index. Among the varieties, Pioneer-27 (hybrid) yielde).d the highest followed by Srikandi (open-pollinated) and Bisi-2 (hybrid) yielded the lowest grain weight per plant. However, there were interaction effects of the treatment factors, meaning that there were different responses between varieties of maize to application of organic or silicate fertilizer in addition to NPK fertilizer in terms of plant height, AGR (average growth rate) of plant height and dry grain yield per plant. Grain yield per plant of Pioneer-27 could be increased with application of organic $(150.79 \mathrm{~g} /$ plant $)$ or silicate $(189.43 \mathrm{~g} / \mathrm{plant})$ compared with NPK only (133.99 g/plant), while that of Srikandi and Bisi-2 could only be increased by addition of silicate (113.83 $\mathrm{g} /$ plant in Srikandi and $103 \mathrm{~g} /$ plant in Bisi-2) compared with NPK only (93.77 g/plant in Srikandi and $82.59 \mathrm{~g} /$ plant in Bisi-2

Cite as: Tatik, A.E., \& Wangiyana, W. (2021). Addition of silicate or organic fertilizer increases growth and yield of several varieties of maize in East Lombok, Indonesia. Journal of Sustainable Dryland Agricultural Systems, 1(1): 13-23. DOI: https://dx.doi.org/10.29303/josdas.v01i1.02

Copyright (C) 2021, Tatik \& Wangiyana

Journal of Sustainable Dryland Agricultural Systems is licensed under a Creative Commons Attribution 4.0 International License.
\end{abstract}




\section{INTRODUCTION}

Maize is one of the multifunction crops, in which almost all parts of the plant can be used as food, feed, or fuel sources. As a food source, maize grains contain starch, proteins, lipids and fibers that are needed by human body (Singh \& Shevkani, 2014). In Indonesia, maize is the second widely cultivated food crop, with a total of harvested maize area of 3,787,367 ha in 2015 , with an average productivity of 5.178 ton/ha in 2015 (https://www.bps.go.id/indicator/53/22/1/produktivitas.html). This average national productivity of maize in Indonesia is still low when compared with the potential productivity of a hybrid maize variety, which mostly range from 10 to 13 ton/ha, as shown in the Balitsereal website (http://balitsereal.litbang.pertanian.go.id/wpcontent/uploads/2016/11/des2016new.pdf).

Maize is one of the high fertilizer consuming crops, especially hybrid maize varieties having high potential of grain yield. Therefore, to achieve a high productivity, application of relevant amount of fertilizers is required, which should be based on site specific fertilizer recommendation (Attanandana $\&$ Yost, 2003). In the sub-Saharan Africa, maize productivity was also very low (only $0.8 \mathrm{t} / \mathrm{ha}$ ) when no fertilizer was applied, but with application of nitrogen fertilizer, grain yield was significantly higher (3.8 t/ha), and increased further (4.3 t/ha) with application of manure and $\mathrm{N}$ fertilizer, even in soil with medium fertility level (Zingore, 2011). Sapkota et al. (2017) also reported that increasing N fertilizer doses from 120 to 160, 200 and up to $240 \mathrm{~kg} / \mathrm{ha}$ significantly increased grain yield of maize, especially under split application of $\mathrm{P}$ fertilizer, although split application of $\mathrm{P}$ fertilizer did not significantly increase grain yield under each dose of $\mathrm{N}$ fertilizer.

In addition to increasing fertilizer doses, increasing frequency of fertilization was also reported to increase yield of maize, especially increasing split application of $\mathrm{N}$ fertilizer (Wangiyana et al., 2010; Davies et al., 2020). Application of a recommended dose of nitrogen fertilizer four times resulted in higher grain yield and weight of 1000 grains of maize when compared with application of the same Urea dose three times. In contrast, increasing fertilization frequency for $\mathrm{P}$ and $\mathrm{K}$ fertilizers in general did not increase maize grain yield. However, when nitrogen fertilizer was applied four times to maize plants fertilized with cattle manure, application of $\mathrm{P}$ and $\mathrm{K}$ fertilizers twice resulted in significantly higher grain yield compared with application of $\mathrm{P}$ and $\mathrm{K}$ fertilizers only once as the basalt fertilizers (Wangiyana et al., 2010). Davies et al. (2020) also reported that increasing split and doses of nitrogen fertilizer increased maize grain yield, nitrogen use efficiency, and rate of nitrogen recovery by maize plants. These mean that increasing both doses and frequency of fertilizer application is very important in an effort to increase grain yield of maize.

Maize plants were also reported to be responsive to organic fertilization. Wangiyana et al. (2010) reported that application of cattle manure of 10 ton/ha in addition to the recommended dose of NPK fertilizers significantly increased growth, grain yield, and other yield components of maize, especially weight of 1000 grains and harvest index. Application of manure in addition to nitrogen fertilizer was also reported to significantly increase maize grain yield in the Sub-Saharan Africa both under low and medium fertility soils (Zingore, 2011). In the dry land of North Lombok, application of soil organic ameliorant in combination with foliar organic fertilizer in addition to the recommended dose of NPK fertilizer was also found to significantly increase biomass weight and grain yield per plot, and reduction of the NPK fertilizer dose to only $70 \%$ the recommended dose in combination with these two types of organic fertilizer also tended to resulted in higher grain yield, when compared with application of the recommended dose of NPK fertilizer (Jaya et al., 2021).

In addition to NPK and organic fertilizers Silicon ( $\mathrm{Si}$ ) has been proven to be beneficial for crop growth and yield, especially for those growing under unfavorable environmental conditions (Liang, 
2018). According to Yan et al. (2018), nowadays Si fertilization in some important crops has been practiced in many countries including China, Thailand, the Philippine, Ceylon, Vietnam, Sri Lanka and India, due to the beneficial effects of Si on growth and yield of various crops. As summarized by Yan et al. (2018), fertilization of crops with Si not only increases yield of the crops, i.e. up to $10.4 \%$ in maize, up to $13.6 \%$ in soybean, and up to $28.5 \%$ in rice, but also improves quality of its yield. In paddy soils, long-term application of Si fertilizer was found to significantly increase abundance of Actinobacteria, enzyme activities, nutrient availability, and composition of soil bacterial community, when compared with paddy soils treated with NPK only or without NPK (Samaddar et al., 2019).

In maize, most researches reported the effects of potassium silicates on crop growth under environmental stress, mostly under salinity and drought stress or water deficiency (Xie et al., 2015; Marques et al., 2016; Ibrahim et al., 2020; Ning et al., 2020). Xie et al. (2015) reported that application of $\mathrm{Si}$ fertilizer significantly increased photosynthetic rates, stomatal conductance, and intercellular $\mathrm{CO}_{2}$ concentration while decreasing transpiration rates, which led to increase growth an yield of maize plants in saline-alkaline soils. Si application in the form of Calcium silicate was also reported to be able to mitigate water deficiency in maize (Marques et al., 2016). Other researchers (Ibrahim et al., 2020) used potassium silicate alleviate damaging effects of deficit irrigation in maize by spraying $\mathrm{K}_{2} \mathrm{SiO}_{3}$ solution to maize leaves, and found $2 \mathrm{mM}$ was the best concentration that can increase shoot dry weight, leaf area index (LAI), nutrient contents, ear length and diameter, and grain yield in maize. In addition, Ning et al. (2020) reported drought stress in maize, either during the vegetative of reproductive stages, can be alleviated by application of Si fertilizer in the form of $\mathrm{Na}_{2} \mathrm{SiO}_{3} \cdot 9 \mathrm{H}_{2} \mathrm{O}$.

This study aimed to examine the effect of application of organic or Si fertilizer in addition to NPK on growth and yield of several varieties of maize in rainfed land of East Lombok, Indonesia, during a dry season.

\section{MATERIALS AND METHODS}

In this study, the experiment was conducted on a rainfed area in Wanasaba village, East Lombok, Indonesia, from July to September, 2015. This piece of land is usually used to grow rice during rainy seasons, followed with direct-seeded soybean or mungbean and then maize crop.

\subsection{Design of the experiment}

The field experiment was designed according to Randomized Complete Block Design, with two treatment factors namely varieties of maize $(\mathrm{V} 1=$ Bisi-2, V2 $=$ Srikandi, V3 $=$ Pioneer 27 $)$ and fertilizer combinations (F1= NPK only, F2= NPK + organic, F3= NPK + silicate fertilizer). Therefore, there were nine treatment combinations, and each combination was made in three blocks as the replications.

\subsection{Implementation of the experiment}

The organic fertilizer used in this experiment was in the form of "bokashi", i.e. EM-4 fermented cattle manure, while the silicate fertilizer, in Indonesia was sold as granule "AGROSIL", which was from the POS Ceramics Co, Ltd, Korea, with 25\% soluble Silicic Acid, 2\% Silicic Acid Magnesia, and 40\% Alkalinity (http://en.posceramics.co.kr/product/product_01_01.php). The maize varieties were hybrid (Bisi-2 and Pioneer-27) and an open-pollinated variety (Srikandi). 
Land preparation was started with formation of raised-beds, after once plowing and once harrowing of the land after harvest of short-duration mungbean crop which was direct-seeded following harvest of rainy-season upland rice. Each raised-bed was made with a size of $3.5 \times 2.0 \mathrm{~m}$ and height of $0.2 \mathrm{~m}$ surrounded with a furrow of $0.3 \mathrm{~m}$ width. For the treatment with addition of organic fertilizer, the "bokashi" was spread on the surface of the raised-beds prior to maize seeding with a dose of $1 \mathrm{~kg} / \mathrm{m}^{2}$. Maize seeds were dibbled under plant spacing of 70 x $20 \mathrm{~cm}$ by dibbling 2-3 seeds per planting hole which was tinned at 2 weeks after seeding (WAS), just before NPK fertilization, to leave only 1 plant per planting hole.

Application of N-P-K fertilizer was done at 2 WAS by dibbling Phonska (NPK 15-15-15) fertilizer $7 \mathrm{~cm}$ deep and $7 \mathrm{~cm}$ apart from maize stem base at a dose of $300 \mathrm{~kg} / \mathrm{ha}$ or $4.5 \mathrm{~g} / \mathrm{plant}$. For the treatment with addition of organic fertilizer (F2), application "bokashi" fertilizer was done one day before seeding, by mixing "bokashi" fertilizer with soil of the raised-bed surface up to $7 \mathrm{~cm}$ depth, with a dose of $10 \mathrm{ton} / \mathrm{ha}$ or $7 \mathrm{~kg}$ per raised-bed. For the treatment with addition of silicate fertilizer, the Agrosil fertilizer was applied on the same time of application of NPK fertilizer by dibbling Agrosil on the opposite side of the NPK hole, with a dose of $400 \mathrm{~kg} / \mathrm{ha}$ or $6 \mathrm{~g} / \mathrm{plant}$. The second application of fertilizer was done at 6 WAS using NPK and Agrosil fertilizers with the same doses and application technique as the first application, but followed with soil piling around the stem base. Other crop maintenance weeding ( 3 times every 3 weeks) and insecticide spray when the tassels start to emerge on some plants and at the milk seed stage, using a systemic insecticide to avoid attack of stem borers and ear borers. Harvest was done by taking only the husked ears and the rest of the above-ground plant parts including the husk leaves were sun dried for weight of dry stover.

\subsection{Observation variables and data analysis}

The observation variables include number of green leaves and plant height at $8 \mathrm{WAS}$, average growth rate (AGR) of plant height, dry stover weight, percentage of dry weight, weight of 100 dry grains, dry grain yield per plant, and harvest index, i.e. percentage of dry seed weight to dry weight of the above-ground plant parts, which were measured from 4 sample plants taken randomly from the diagonal line of the raised-bed.

The data were analyzed with Analysis of Variance (ANOVA) and Tukey's HSD (Honestly Significant Difference) using the statistical software CoStat for Windows ver. 6.303. Graphics were made using MS Excel for Windows based on the individual means and standard error of the treatment combination (Riley, 2001).

\section{RESULTS AND DISCUSSION}

The summary of the ANOVA results in Table 1 shows that both factor had significant effects on almost all variables except the effect of varieties on percentage of dry weight and the effect of fertilizer combinations on harvest index. However, there were significant interaction effects between the two factors but they were significant only on plant height at 8 WAS, AGR of plant height, and dry grain yield per plant.

Based on the interaction effect of the treatment factors on plant height at 8 WAS it an be seen from Fig. 1 that fertilizer combinations did not affect plant height of Bisi-2 variety but plant height of Srikandi and Pioneer-27 varieties was significantly different, i.e. higher due to addition of organic or silicate fertilizer in addition to the NPK fertilizers. The trends of AGR differences among fertilizer 
combinations were similar to plant height of Srikandi and Pioneer-27 varieties, which were highest in maize plants supplied with NPK and silicate fertilizer. However, the opposite trends occurred in the Bisi-2 variety, in which the highest AGR was in maize plants fertilized with NPK only. Since the measurement of plant height was done every two weeks, this could mean that in the beginning of measurements, plant height was higher in the Bisi-2 plants fertilized with NPK + silicate followed with NPK + organic fertilizers compared with NPK only, while the final height was similar among the three fertilizer combinations (Fig. 1).

Table 1. Summary of ANOVA results for all observation variables

\begin{tabular}{|c|c|c|c|c|c|}
\hline Observation variables & Blocks & $\begin{array}{c}\text { Maize } \\
\text { Varieties }\end{array}$ & $\begin{array}{c}\text { Fertilizer } \\
\text { combination }\end{array}$ & Interaction & $\begin{array}{l}\text { Coefficient of } \\
\text { variation }(\%)\end{array}$ \\
\hline Green leaf number per plant at 8 weeks & $\mathrm{ns}$ & $* *$ & $* *$ & ns & 8.52 \\
\hline Plant height at 8 weeks after seeding & ns & $* * *$ & $* * *$ & $* *$ & 5.13 \\
\hline Average growth rate (AGR) plant height & ns & $* * *$ & $*$ & $* * *$ & 7.90 \\
\hline Dry stover weight per plant & ns & $* * *$ & $* * *$ & ns & 5.53 \\
\hline Weight of 100 dry grains & ns & $* * *$ & $* * *$ & ns & 7.38 \\
\hline Dry grain yield per plant & ns & $* * *$ & $* * *$ & $* *$ & 5.64 \\
\hline Harvest index & ns & $* * *$ & ns & ns & 4.96 \\
\hline
\end{tabular}

Remarks: $\mathrm{ns}=$ non-significant; $*, * *, * * *=$ significant at $p$-value $<0.05$, p-value $<0.01$ and $p$-value $<0.001$ respectively

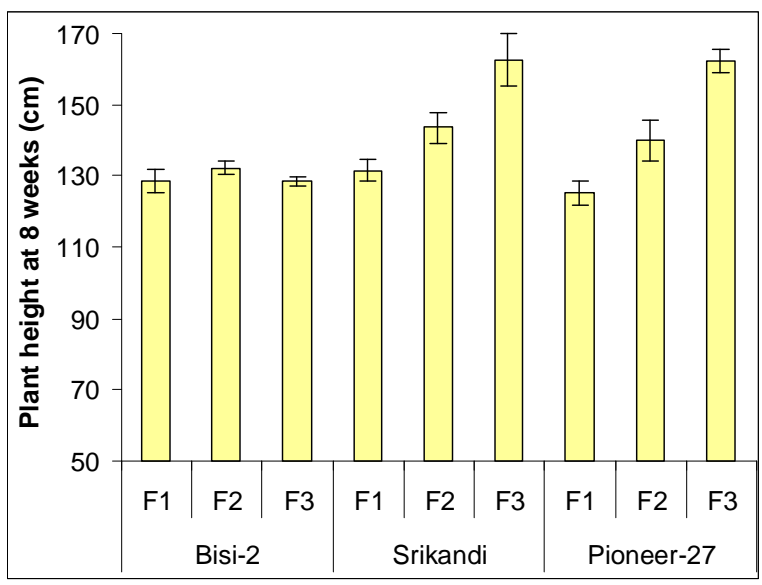

Fig 1. Average (Mean $\pm \mathrm{SE})$ plant height $(\mathrm{cm})$ for each fertilizer combination and variety

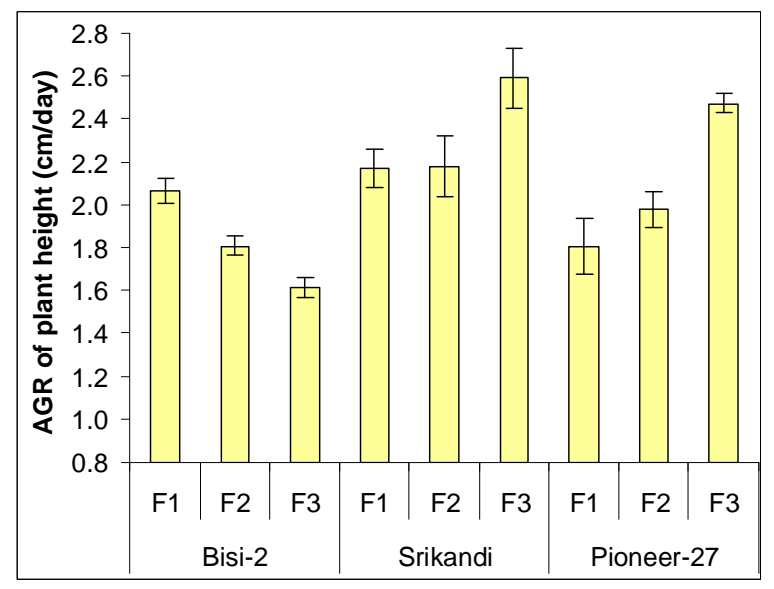

Fig 2. Average (Mean \pm SE) AGR of plant height $(\mathrm{cm} /$ day) for each fertilizer combination and variety

In relation to weight of 100 dry grains, fertilizer combinations showed significant effects in Bisi2 and Srikandi varieties, but in Pioneer-27 variety, addition of organic fertilizer did not result in different weight of 100 dry grains (Fig. 3). Addition of organic fertilizer also could not increase grain yield of Bisi-2 and Srikandi varieties, but averages of grain yield of Pioneer-27 were significantly different between fertilizer combinations in which addition of both organic and silicate fertilizers in addition to NPK fertilizer significantly increased grain yield (Fig. 4). These indicate different responses between varieties of maize to addition of organic fertilizer, as can be seen from Fig. 4 that 
addition of organic fertilizer did not significantly increase grain yield of Bisi-2 and Srikandi varieties but the increase in grain yield was significant in the Pioneer-27 variety.

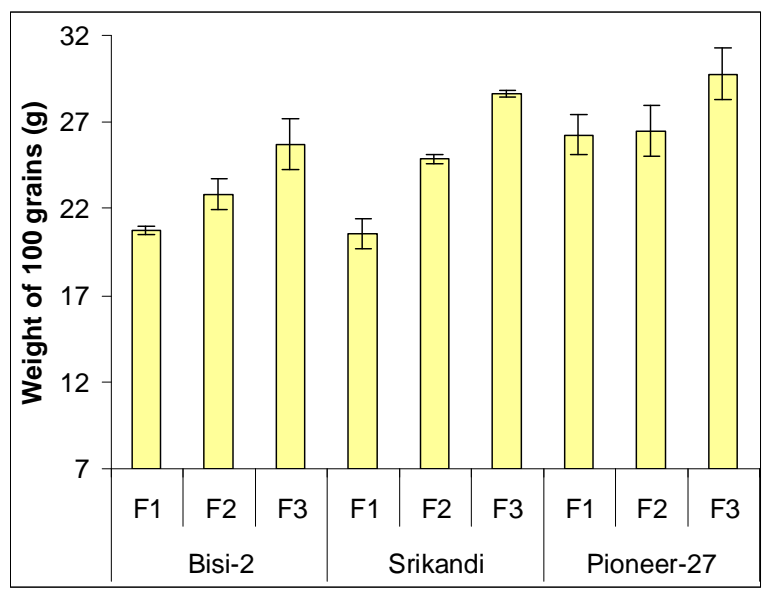

Fig 3. Average (Mean \pm SE) weight of 100 dry grains $(\mathrm{g})$ for each fertilizer combination and variety of maize

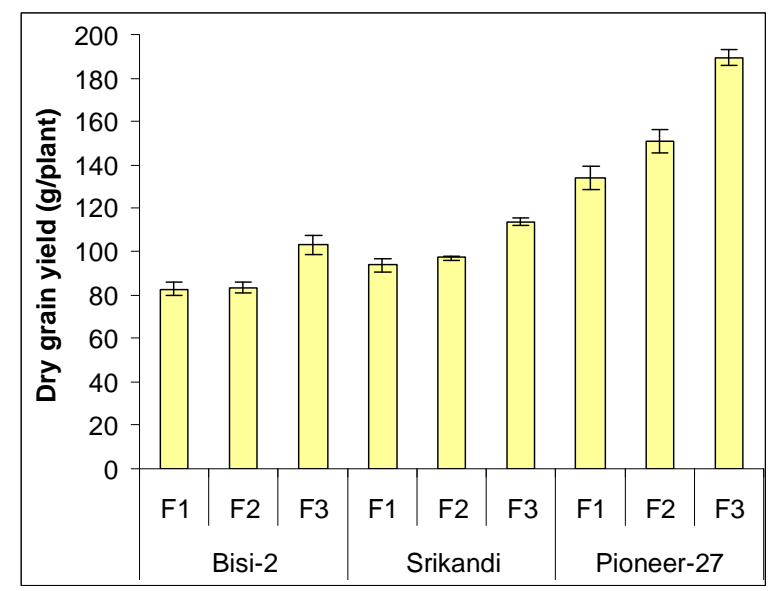

Fig 4. Average (Mean \pm SE) dry grain yield (g/plant) for each fertilizer combination and variety of maize

This could be due to the very low organic fertilizer amended to the surface of the raised-beds, i.e. only 10 ton/ha, which was mixed with the surface soil. The experimental results presented by Motsi et al. (2019) also showed no significant differences in grain yield between levels of cattle manure application (0, 2.5 and 5 ton/ha) except in the treatments without application of $\mathrm{N}$ fertilizer, maize grain yield was significantly different between application of 0 and 5 ton/ha cattle manure, in which cattle manure was spread evenly on the bed surface. Hani et al. (2019) also applied cattle manure by mixing it with the soil surface prior to planting in their experiment with six treatments including control $(0,4,8,12,16$ and 20 ton/ha), and they found that there was a significant effect of cattle manure doses on total $\mathrm{N}$ uptake and $\mathrm{N}$-use efficiency by maize plants. However, the significant different in total $\mathrm{N}$ uptake over the control was from an application dose of $12 \mathrm{ton} / \mathrm{ha}$, while the dose of 4 and 8 ton/ha did not show a significant different from the control (Hani et al., 2019).

If the application of the organic fertilizer was done by placing the fertilizer around below the seeds in the planting holes then under the application of 10 ton/ha cattle manure would result in an application dose of $150 \mathrm{~g} / \mathrm{plant}$. By this application technique, the experimental results reported by Wangiyana et al. (2010) indicated that application of 10 ton/ha cattle manure significantly increased grain yield per plant, weight of 1000 grains, harvest index, and other growth variables, in which the cattle manure was applied by burying it in the maize rows before seeding with a dose of $1.5 \mathrm{~kg}$ per row of 10 maize plants (10 ton/ha) of Bisi-2 variety. Wang et al. (2017) also reported that application of organic manure of $52.5 \mathrm{ton} / \mathrm{ha}$ spread evenly on the plot surface significantly increased maize grain yield, especially under the highest plant density of 90,000 plants compared with 75 and 60 plants/ha in the second year of manure application.

However, application of silicate fertilizer in addition to NPK fertilizers on average resulted in higher increase in growth variables (Table 2) and yield components (Table 3) of maize compared with adding cattle manure. In relation to yield response of different maize varieties, application of silicate fertilizer in addition to NPK fertilizers also significantly increased weight of 100 dry grains (Fig. 3) and dry grain yield per plant in all maize varieties tested (Fig. 4), which indicates significant contribution of silicate fertilizer in increasing maize yield compared with application of NPK 
fertilizers only. This means that $\mathrm{Si}$ is beneficial in increasing yield of maize under rainfed conditions (Liang, 2018).

Many have reported that application of silicate fertilizers improved tolerance of various crops to environmental stresses. Xie et al. (2015) reported that application of Si fertilizer significantly increased growth and yield of maize plants in saline-alkaline soils. From results of pot experiments, Zaimenko et al. (2018) also reported that application of silicates mixed with organic fertilizer alleviated reduction of shoot and root biomass production and photosynthetic pigment contents imposed by higher salinity levels. Si application can also mitigate water deficiency (Marques et al., 2016), and alleviate damaging effects of deficit irrigation in maize. Ning et al. (2020) also reported that $\mathrm{Si}$ fertilizer in the form of $\mathrm{Na}_{2} \mathrm{SiO}_{3} .9 \mathrm{H}_{2} \mathrm{O}$ can alleviate drought stress in maize, either during the vegetative of reproductive stages.

Tabel 2. Average green leaf number and plant height at 8 WAS, AGR plant height and dry stover weight of maize for each variety and fertilizer combination

\begin{tabular}{lcccc}
\hline Treatments & $\begin{array}{c}\text { Green leaf number } \\
\text { per plant at 8 WAS }\end{array}$ & $\begin{array}{c}\text { Plant height }(\mathbf{c m}) \text { at } \\
\text { 8 WAS }\end{array}$ & $\begin{array}{c}\text { AGR plant height } \\
\text { (cm/day) }\end{array}$ & $\begin{array}{c}\text { Dry stover weight } \\
\text { (g/plant) }\end{array}$ \\
\hline V1: Bisi-2 & $11.44 \mathrm{a}$ & $129.69 \mathrm{~b}$ & $1.83 \mathrm{c}$ & $175.52 \mathrm{~b}$ \\
V2: Srikandi & $9.82 \mathrm{~b}$ & $145.90 \mathrm{a}$ & $2.31 \mathrm{a}$ & $188.92 \mathrm{a}$ \\
V3: Pioneer-27 & $11.56 \mathrm{a}$ & $142.44 \mathrm{a}$ & $2.09 \mathrm{~b}$ & $201.27 \mathrm{a}$ \\
Tukey's HSD & 1.13 & 8.70 & 0.20 & 12.67 \\
\hline B1: NPK only & $10.13 \mathrm{~b}$ & $128.32 \mathrm{c}$ & $2.01 \mathrm{~b}$ & $170.50 \mathrm{~b}$ \\
B2: NPK + organic & $10.84 \mathrm{ab}$ & $138.62 \mathrm{~b}$ & $1.99 \mathrm{~b}$ & $181.21 \mathrm{~b}$ \\
B3: NPK + silicate & $11.84 \mathrm{a}$ & $151.09 \mathrm{a}$ & $2.23 \mathrm{a}$ & $214.00 \mathrm{a}$ \\
Tukey's HSD & 1.13 & 8.70 & 0.20 & 12.67 \\
\hline
\end{tabular}

Remarks: Means in the same column followed by the same letters are not significantly different between treatments of each factor

Our results also showed that application of silicate fertilizer, in addition to NPK fertilizers, significantly improved growth (Table 2) and yield components of maize (Table 3) compared with application of NPK fertilizers only, except for harvest index, in which the increase was not significant. According to results of a factorial experiment reported by Zaimenco et al. (2018), application of silicates could increase photosynthetic pigments, and growth of roots and shoots, and biomass production of maize plants since the seedling growth stages. Xie et al. (2014) also reported that silicate fertilizer increased chlorophyll content and photosynthetic rates of maize plants on alluvial soil. In this study, average number of green leaves per plant was also highest in maize plants receiving silicate in addition to NPK fertilizer, which also means higher chlorophyll content per plant, like the results reported by Xie et al. (2014). When growth and biomass production are increased by silicate fertilizers since the seedling growth stages of maize then it is logical that the final growth results, such as average number of green leaves prior to anthesis ( 8 WAS), plant height and dry stover weight per plant were higher in maize plants receiving application of silicate fertilizer (B3) in addition to NPK fertilizer compared with those receiving NPK fertilizers only (Table 2). From results of correlation analysis, these growth variables (plant height and green leaf number prior anthesis, and dry stover weight at harvest) and harvest index also showed significant correlation with dry grain yield per plant (Table 4). 
Tabel 3. Average weight of 100 dry grains, dry grain yield per plant, and harvest index of maize for each variety and fertilizer combination

\begin{tabular}{lccc}
\hline Treatments & Weight of 100 dry grains (g) & Dry grain yield (g/plant) & Harvest index (\%) \\
\hline V1: Bisi-2 & $23.11 \mathrm{~b}$ & $89.65 \mathrm{c}$ & $33.81 \mathrm{~b}$ \\
V2: Srikandi & $24.70 \mathrm{~b}$ & $101.58 \mathrm{~b}$ & $35.11 \mathrm{~b}$ \\
V3: Pioneer-27 & $27.52 \mathrm{a}$ & $158.07 \mathrm{a}$ & $43.78 \mathrm{a}$ \\
Tukey's HSD & 2.25 & 7.99 & 2.27 \\
\hline B1: NPK only & $22.54 \mathrm{~b}$ & $103.45 \mathrm{~b}$ & $37.37 \mathrm{a}$ \\
B2: NPK + organic & $24.73 \mathrm{~b}$ & $110.41 \mathrm{~b}$ & $37.27 \mathrm{a}$ \\
B3: NPK + silicate & $28.07 \mathrm{a}$ & $135.44 \mathrm{a}$ & $38.07 \mathrm{a}$ \\
Tukey's HSD & 2.25 & 7.99 & 2.27 \\
\hline
\end{tabular}

Remarks: Means in the same column followed by the same letters are not significantly different between treatments of each factor

Table 4. Coefficients of correlation between observation variables and their p-values

\begin{tabular}{lcccccc}
\hline $\begin{array}{l}\text { Correlation coefficients } \\
\text { and p-values between } \\
\text { variables }\end{array}$ & $\begin{array}{c}\text { Stover dry } \\
\text { weight per } \\
\text { plant }\end{array}$ & $\begin{array}{c}\text { Weight of } \\
\text { 100 dry } \\
\text { grains }\end{array}$ & $\begin{array}{c}\text { Dry grain } \\
\text { yield per } \\
\text { plant }\end{array}$ & $\begin{array}{c}\text { Harvest } \\
\text { index }\end{array}$ & $\begin{array}{c}\text { Green leaf } \\
\text { number at } \\
\mathbf{8} \text { WAS }\end{array}$ & $\begin{array}{c}\text { Plant } \\
\text { height at 8 } \\
\text { WAS }\end{array}$ \\
\hline Weight of 100 dry grains & 0.795 & & & & & \\
p-value & $\mathbf{0 . 0 0 0}$ & & & & & \\
Dry grain yield per plant & 0.658 & 0.670 & & & & \\
p-value & $\mathbf{0 . 0 0 0}$ & $\mathbf{0 . 0 0 0}$ & & & & \\
Harvest index (\%) & 0.313 & 0.441 & 0.914 & & & \\
p-value & 0.112 & $\mathbf{0 . 0 2 1}$ & $\mathbf{0 . 0 0 0}$ & & & \\
Green leaf number at 8 WAS & 0.455 & 0.424 & 0.441 & 0.287 & & \\
p-value & $\mathbf{0 . 0 1 7}$ & $\mathbf{0 . 0 2 7}$ & $\mathbf{0 . 0 2 1}$ & 0.146 & & \\
Plant height at 8 WAS & 0.612 & 0.634 & 0.506 & 0.294 & 0.187 & \\
$\quad$ p-value & $\mathbf{0 . 0 0 1}$ & $\mathbf{0 . 0 0 0}$ & $\mathbf{0 . 0 0 7}$ & 0.137 & 0.351 & \\
AGR of plant height per day & 0.366 & 0.319 & 0.321 & 0.195 & -0.126 & 0.875 \\
p-value & 0.060 & 0.105 & 0.103 & 0.330 & 0.532 & $\mathbf{0 . 0 0 0}$ \\
\hline
\end{tabular}

Multiple regression analysis resulted in almost $100 \% \mathrm{R}^{2}$ between dry grain yield per plant, as the response variable, and the $\mathrm{X}$ variables consisting of plant height 8 WAS (X1), green leaf number 8 WAS (X2), dry stover weight (X3), and harvest index (X4), with a regression equation $\mathrm{Y}==-216+$ $0.103 \mathrm{X} 1+1.13 \mathrm{X} 2+0.538 \mathrm{X} 3+5.44 \mathrm{X} 4\left(\mathrm{R}^{2}=99.1 \%\right)$, with the $\mathrm{p}$-values for each $\mathrm{X}$-variables as listed in Table 5.

Table 5. Statistics of the regression between grain yield (Y) and plant height (X1), leaf number (X2), stover weight (X3) and harvest index (X4)

\begin{tabular}{lrrrc}
\hline Predictor & Coefficient & SE Coef & \multicolumn{1}{c}{ T } & P-value \\
\hline Constant & -216.128 & 8.225 & -26.28 & 0.000 \\
Plant height 8 WAP & 0.10300 & 0.05901 & 1.75 & 0.095 \\
Leaf number 8 WAP & 1.1273 & 0.5962 & 1.89 & 0.072 \\
Dry stover weight & 0.53828 & 0.04067 & 13.24 & 0.000 \\
Harvest index & 5.4400 & 0.1505 & 36.15 & 0.000 \\
\hline
\end{tabular}


When the multiple regression analysis was run in each treatment of fertilizer combination, it can be seen from Table 6 that under fertilizer combination of NPK and silicate fertilizer (B3), the contribution of harvest index was highest, with the highest regression coefficient of 6.35 compared with under B2 with a regression coefficient of 4.88 or under B1 with a regression coefficient of only 4.54 (Table 6).

Table 6. Regression equations between grain yield $(\mathrm{Y})$ and plant height $(\mathrm{X} 1)$, leaf number (X2), stover weight (X3) and harvest index (X4) for each fertilizer combination

\begin{tabular}{lcc}
\hline Fertilizer combination & \multicolumn{1}{c}{ Regression equation } & $\mathbf{R}^{\mathbf{2}}$ \\
\hline P1: NPK only & $\mathrm{Y}=-165-0.0850 \mathrm{X} 1+0.709 \mathrm{X} 2+0.599 \mathrm{X} 3+4.54 \mathrm{X} 4$ & $99.8 \%$ \\
P2: NPK+organic & $\mathrm{Y}=-197-0.0284 \mathrm{X} 1+1.19 \mathrm{X} 2+0.644 \mathrm{X} 3+4.88 \mathrm{X} 4$ & $99.8 \%$ \\
P3: NPK+silicate & $\mathrm{Y}=-204-0.107 \mathrm{X} 1-1.08 \mathrm{X} 2+0.594 \mathrm{X} 3+6.35 \mathrm{X} 4$ & $99.9 \%$ \\
\hline
\end{tabular}

Addition of silicate fertilizer not only increased grain yield per plant, it also increased weight of 100 dry grains (Table 3), and this yield component also showed significant correlation with number of green leaves and plant height at 8 WAS and dry stover weight per plant (Table 4). Taller maize plants and higher number of green leaves prior to anthesis could result in higher photosynthetic rates during reproductive stages of the maize plants, and this could be the reason why higher plant height and number of green leaves prior to anthesis (Table 2) correspond with higher grain yield per plant and higher weight of 100 dry grains (Table 3). Among the three varieties of maize tested, the hybrid variety "Pioneer-27" seems to be more responsive to additional fertilization with both silicate and organic fertilizer in the form of cattle manure compared with the hybrid variety "Bisi-2" and the open-pollinated variety "Srikandi", especially in terms of grain yield per plant, as can be seen from Fig. 4. However, between both additional fertilizers, maize varieties tested were more responsive to addition of silicate than cattle manure. Therefore, it can be concluded that addition of silicate fertilizer is highly beneficial in increasing growth and yield components of maize, especially the hybrid variety "Pioneer-27" under rainfed growing condition.

\section{CONCLUSION}

It can be concluded that addition of silicate fertilizer more significantly increased growth and yield of maize compared with addition of organic fertilizer in addition to NPK fertilizers. Among the varieties, Pioneer-27 (hybrid) was the most responsive to addition of silicate fertilizer and yielded the highest followed by Srikandi (open-pollinated) and Bisi-2 (hybrid) yielded the lowest grain weight per plant.

\section{ACKNOWLEDGEMENT}

Data used in this article are part of the $\mathrm{S} 1$ thesis experiment of the first author when she was a student in the Faculty of Agriculture, University of Mataram, under supervision of the second author. 


\section{AUTHORS' CONTRIBUTION}

The Author1 conducted the entire field experiment under supervision of the Author2, who reanalyzed the data, translated the first Indonesian draft into English and finished the English draft using the article template, and finally submitted the manuscript.

\section{REFERENCES}

Attanandana, T., \& Yost, R.S. (2003). A site-specific nutrient management approach for maize. Better Crops International, 17(1): 3-7.

Davies, B., Coulter, J.A., \& Pagliari, P.H. (2020). Timing and rate of nitrogen fertilization influence maize yield and nitrogen use efficiency. Plos One, May 29, 2020. https://doi.org/10.1371/journal.pone.0233674.

Hani, N.B., Al-Ramamneh, E.A., Haddad, M., Al-Tawaha, A.R., \& Al-Satari, Y. (2019). The impact of cattle manure on the content of major minerals and nitrogen uptake from $15-\mathrm{N}$ isotope labeled Ammonium Sulphate fertilizer in maize (Zea mays L.) plants. Pak. J. Bot., 51(1): 185-189. https://dx.doi.org/10.30848/PJB2019-1(11).

Ibrahim, M.F.M., El-Samad, G.A., Ashour, H., El-Sawy, A.M., Hikal, M., Elkelish, A., El-Gawad, H.A., El-Yazied, A.A., Hozzein, W.N., \& Farag, R. (2020). Regulation of agronomic traits, nutrient uptake, osmolytes and antioxidants of maize as influenced by exogenous potassium silicate under deficit irrigation and semiarid conditions. Agronomy, 10, 1212. https://dx.doi.org/10.3390/agronomy10081212.

Jaya, I.K.D., Suheri, H., \& Wangiyana, W. (2021). Can organic soil ameliorant and foliar organic fertilizer improve maize yield and reduce inorganic fertilizers input in a dryland semiarid? IOP Conf. Ser.: Earth Environ. Sci., 712, 012012. https://dx.doi.org/10.1088/17551315/712/1/012012.

Liang, Y.C. (2018). Beneficial roles silicon plays in agriculture. Journal of Integrative Agriculture, 17(10), 2137.

Marques, D.J., Ferreira, M.M, Lobato, A.K.D.S., de Freitas, W.A., Carvalho, J.D.A., Ferreira, E.D., \& Broetto, F. (2016). Potential of calcium silicate to mitigate water deficiency in maize. Bragantia, Campinas, 75(3), 275-285. http://dx.doi.org/10.1590/1678-4499.446.

Motsi, T., Kugedera, A.T., \& Kokerai, L.K. (2019). Role of cattle manure and inorganic fertilizers in improving maize productivity in semi-arid areas of Zimbabwe. Octa Journal of Environmental Research, 7(3), 122-129. Available online http://www.sciencebeingjournal.com.

Ning, D., Qin, A., Liu, Z., Duan, A., Xiao, J., Zhang, J., Liu, Z., Zhao, B., \& Liu, Z. (2020). Siliconmediated physiological and agronomic responses of maize to drought stress imposed at the $\begin{array}{llllll}\text { vegetative and } & \text { reproductive } & \text { stages. }\end{array}$ https://dx.doi.org/10.3390/agronomy10081136.

Riley, J. (2001). Presentation of statistical analyses. Experimental Agriculture, 37, 115-123.

Samaddar, S., Truu, J., Chatterjee, P., Truu, M., Kim, K., Kim, S., Seshadri, S., \& Sa, T. (2019). Long-term silicate fertilization increases the abundance of Actinobacterial population in paddy soils. Biology and Fertility of Soils, https://doi.org/10.1007/s00374-018-01335-6.

Sapkota, A., Shrestha, R.K., \& Chalise, D. (2017). Response of maize to the soil application of nitrogen and phosphorous fertilizers. Int. J. Appl. Sci. Biotechnol., 5(4), 537-541. https://dx.doi.org/10.3126/ijasbt.v5i4.18777. 
Singh, N., Kaur, A., \& Shevkani, K. (2014). Maize: grain structure, composition, milling, and starch characteristics. In: D.P. Chaudhary et al. (eds.), Maize: nutrition dynamics and novel uses. Springer India, New Delhi, India, pp. 65-91. https://dx.doi.org/10.1007/978-81-322-1623-0_5.

Wang, X., Ren, Y., Zhang, S., Chen, Y., \& Wang, N. (2017). Applications of organic manure increased maize (Zea mays L.) yieldand water productivity in a semi-arid region. Agricultural Water Management, 187, 88-98. http://dx.doi.org/10.1016/j.agwat.2017.03.017.

Wangiyana, W., Hanan, M., \& Ngawit, I.K. (2010). Increasing yield of hybrid maize var. Bisi-2 through application of cattle manure and an increase in application frequencies of Urea and mixture of SP-36 and $\mathrm{KCl}$ fertilizers. Crop Agro, 3(1), 51-58.

Xie, Z., Song, F., Xu, H., Shao, H., \& Song, R. (2014). Effects of Silicon on photosynthetic characteristics of maize (Zea mays L.) on alluvial soil. The Scientific World Journal. Vol. 2014. http://dx.doi.org/10.1155/2014/718716.

Xie, Z., Song, R., Shao, H., Song, F., Xu, H., \& Lu, Y. (2015). Silicon improves maize photosynthesis in saline-alkaline soils. The Scientific World Journal, Vol. 2015. http://dx.doi.org/10.1155/2015/245072.

Yan, G.C., Nikolic, M., Ye, M.J., Xiao, Z.X., \& Liang, Y.C. (2018). Silicon acquisition and accumulation in plant and its significance for agriculture. Journal of Integrative Agriculture, 17(10), 2138-2150.

Zaimenko, N.V., Didyk, N.P., Pavliuchenko, N.A., Ivanytska, B.O., Kharytonova, I.P., \& Rositska, N.V. (2018). Natural silicates mixed with organic fertilizers enhance corn adaptation to salt stress and improve physical characteristics of sandy soil. Journal of Crop Improvement, 32(2), 188-207. https://doi.org/10.1080/15427528.2017.1405856.

Zingore, S. (2011). Maize productivity and response to fertilizer use as affected by soil fertility variability, manure application, and cropping system. Better Crops, 95(1), 4-6. 